\title{
Measuring the Effectiveness and Innovative Capability: Case Lahti University Consortium
}

\author{
Sanna PEKKOLA* - Juhani UKKO ${ }^{* *}$
}

\section{Introduction}

In 2001-2003, the Ministry of Education worked together with Finnish universities to establish six university consortiums in Finland alongside the 20 universities that already existed. The university consortiums were located in cities that already had some university activities but did not have their own university. One of the six university consortiums was established in the City of Lahti. The Lahti University Consortium is a network university that was established by four Finnish universities and that offers services provided by departments of these universities. The Lahti University Consortium brings together the knowledge base of Lahti's trade and in Newbury Park, CA ustry, the profound expertise of the Päijät-Häme region and the firm scientific expertise of the parent universities. The main purpose of the Lahti University Consortium is to raise the level of education and know-how and to serve the trade and industry in the Lahti region, and the region itself, through university research, development and education. Thus, the Lahti University Consortium advances the welfare of the Lahti Region $<$ http://www.lahdenyliopistokeskus.fi/>.

The units of the Lahti University Consortium are listed below:

- University of Helsinki, Open University, Lahti,

- University of Helsinki, Palmenia Center for Research and Continuing Education,

\footnotetext{
Sanna Pekkola - researcher; Department of Industrial Management, Faculty of Technology Management, Lappeenranta University of Technology, Lahti Unit, Saimaankatu 11, FI-15140 Lahti, Finland;. <sanna.pekkola@lut.fi>

** Juhani Ukko - project manager; Department of Industrial Management, Faculty of Technology Management, Lappeenranta University of Technology, Lahti Unit, Saimaankatu 11, FI-15140 Lahti, Finland; <juhani.ukko@lut.fi>
} 
- University of Helsinki, Department of Ecological and Environmental Sciences,

- Helsinki University of Technology, Lahti Center,

- Lappeenranta University of Technology, Lahti Unit,

- Lahti Science Library,

- Coordination Unit of the Lahti University Consortium,

- Tampere University of Technology, Lahti Unit.

The main tasks of the university consortiums have been defined as facilitating social and regional effectiveness of research and education, and developing innovativeness. For that reason, there is a need to create a measurement system for evaluating how well the university consortiums carry out these tasks and what kinds of regional impacts they generate. The measurement of regional impacts, however, includes many challenges. Regional impacts usually emerge after a long period of time, and it may be difficult to show that the impacts result from the activities of the university consortiums alone. In addition, profiles of units in different universities may differ a great deal because they operate mainly under administration of the parent university. (Poranen, 2006).

As a whole, the Lahti University Consortium plays an important role in the Regional Innovation System of the Lahti region (see e.g. Harmaakorpi, 2004; 2006). According to Cooke et al. (1997), it is possible to describe an innovation system in abstract modelling terms by including organisational elements and linkages between them. The main elements are university research, research institutes, technology-transfer agencies, consultants, skills-development organisations, public and private funding organisations and, of course, firms, large and small, plus non-profit organisations involved in innovation. Linkages can be specified in terms of flows of knowledge and information, flows of investment funding, flows of authority, and even more informal arrangements such as networks, clubs, fora and partnerships. As can be seen from Figure 1, the Lahti University Consortium has a double role in the regional innovation system. The university units both utilise external knowledge and information in their research and development activities, and produce new information, knowledge, methods and tools for the needs of the other operators in the regional innovation system. 
Fig. 1: Regional innovation system. Revised from Harmaakorpi Tura (2008)

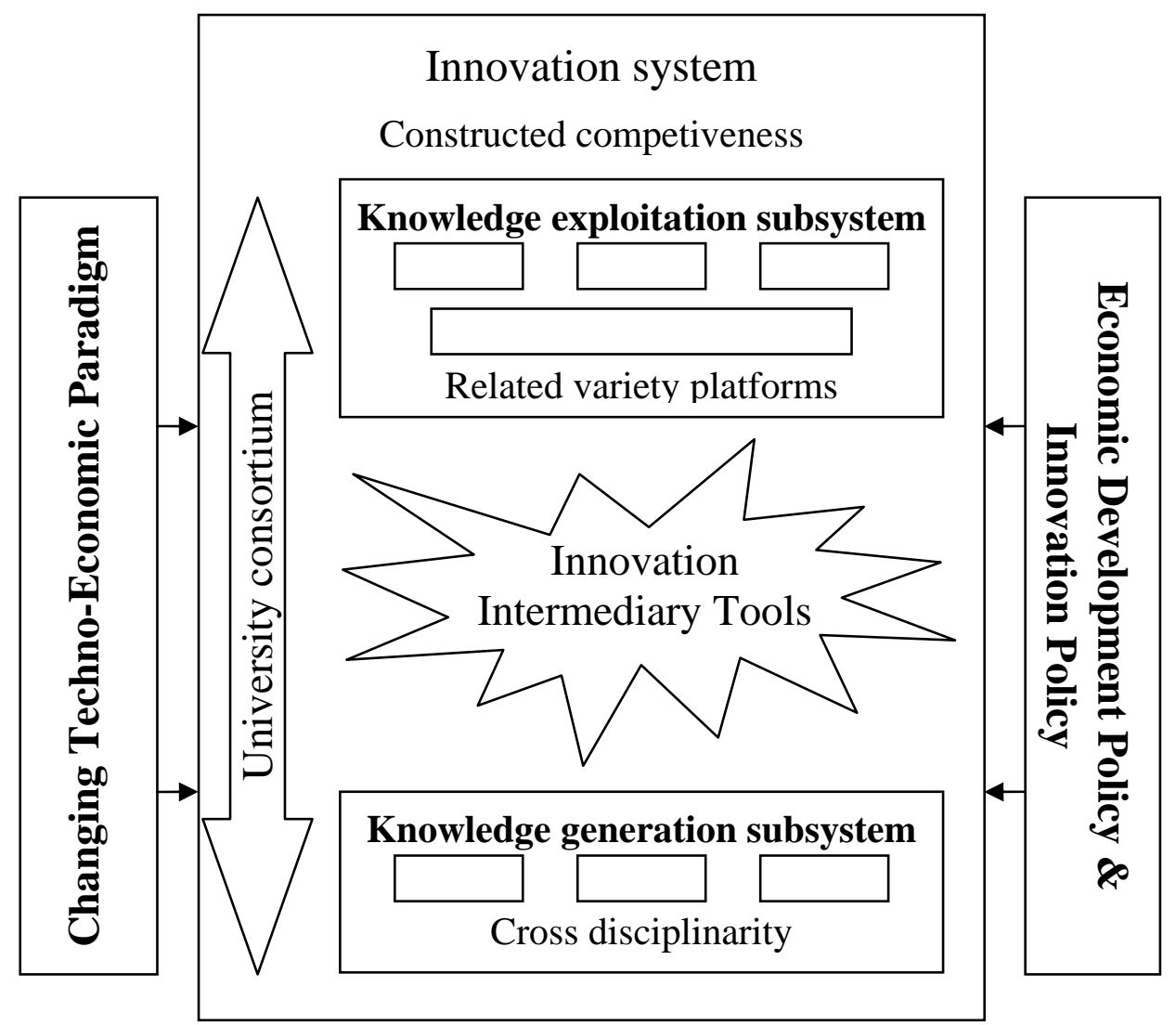

Most measures of innovations at the regional level are connected to inputs of innovation activities (e.g. R\&D expenses) and outputs of innovation activities (e.g. patents) (Tura - Harmaakorpi, 2008; Pekkola et al., 2008). The problem is that these kinds of measures usually pay attention only to certain types of innovations and ignore, for example, service innovations (see e.g. Tura - Harmaakorpi, 2005; Romijn Albaladejo, 2000). Another important challenge from the viewpoint of a regional innovation system is to examine what happens between the inputs and outputs; in other words, how does the innovation system actually work. The present study focuses on designing a measurement system for evaluating the effectiveness and innovative capability of the Lahti University Consortium. 


\section{Objective of the study}

One of the main issues in developing the innovation environment of the Lahti region concerns creating a holistic evaluation platform that covers all elements of the regional innovation system. The objective of the study is to create a measurement system for evaluating the effectiveness and innovative capability of the Lahti University Consortium. This measurement system is a central part of the holistic evaluation platform.

\section{Challenges of performance measurement in the public sector}

The public sector is devoting more attention, time and money to performance management, measurement and evaluation than before (McAdam et al., 2005). Many public sector organisations have implemented performance measurement systems, such as Balanced Scorecard (Kaplan - Norton, 1992). However, such adaptation of private sector approaches has caused a number of difficulties (McAdam et al., 2005; Adcroft - Willis, 2005). Private sector companies usually focus on a higher financial performance, whereas public sector organisations have a variety of stakeholders with different needs. There is also a danger that private sector methods may bias the reality of the public sector to correspond with the reality of the private sector (Bendheim - Graves, 1998). It is important to remember that, as well as different tasks connected to the needs of stakeholders, the public sector has responsibilities defined by legislation. Therefore, one of the main challenges in public sector performance measurement has been considered to be its multiple and even complex group of stakeholders (Greiling, 2005; Hassan, 2005).

Rantanen and his colleagues (2007a) identified specific problems faced by Finnish public sector organisations in designing and implementing performance measurement systems. They are as follows: (i) many stakeholders with conflicting needs; (ii) undefined end products and goals; (iii) lack of ownership of the property, and (iv) poor management skills. The main reasons for the problems related to performance measurement in public organisations were identified as follows (Rantanen et al., 2007a; Rantanen et al., 2007b): 
- difficulties in solving conflicts between the needs of different stakeholders (i.e. not clear what should be measured);

- difficulties in target setting (i.e. not clear what the goal of the operations should be);

- representatives of different stakeholder groups influence the development of individual measures at too detailed a level;

- the personnel does not understand the objectives of the measurement development;

- too many persons responsible for the measurement development leads to non-responsibility;

- the personnel does not see the usefulness of the project with regard to their work, and hence ignores or resists it;

- overlapping projects hamper the measurement project because they take up resources.

It seems that when developing and implementing performance measurement systems in the public sector, the starting point and key driver should be the stakeholders' needs and expectations. The public sector should prefer performance measurement systems that pay sufficient attention to stakeholders. For example, Performance Prism (Neely et al., 2001) was found to be suitable in identifying and categorising stakeholders of an organisation. Some other differences between the private and public sector can also be found as regards performance measurement. For literature highlights the role of rewarding. Public sector organisations, however example, in the context of performance measurement the current, do not have the same financial resources for rewarding their employees as private sector organisations do because the municipal economy limits financial rewarding (Pekkola et al., 2007; Ukko et al., 2008).

In the current study, the design of the measurement system for evaluating the effectiveness of the Lahti University Consortium meets most of the challenges mentioned above. The Lahti University Consortium is a network of different university units, and it is also included in the network of regional innovation systems. This means that there are many stakeholders that have to be taken into account in the definition of the measurement system. The Lahti University Consortium has to serve, for example, the needs of both companies and residents of the Lahti region, as well as the needs of the main universities. In the future, it is possible that the measurement system and its results will be used as criteria for financing the university units. 


\section{Innovative capability}

Innovation capability is widely seen as a driving force in building regional competitive advantages. The present paradigm emphasises the non-linear and interactive nature of innovative processes, which creates a demand to build a regional innovation environment. (Tura - Harmaakorpi 2005) Regional innovative capability refers to the joint innovation capability of the firms and other organisations in a region. Thus, it is made up of the innovation capability not only of individual actors, but also of the entire innovation network, which at the best can be much more than just the sum of its parts (Tura - Harmaakorpi 2005). Teece and Pisano (1998) define innovation capability as an actor's ability to sense changes in an environment and exploit existing resources and competencies in order to create competitive advantage by innovation activities. Consequently, the term 'regional innovation capability' refers to the ability of a regional innovation network to exploit and renew existing resource configurations in order to create a sustainable competitive advantage by innovation activities in a constantly changing environment. Therefore, it is formed by the innovation capability of individual actors and innovation networks taking part in the regional innovation system.

\section{Methodology}

The study was conducted in the Päijät-Häme region, Finland, in 2007. The Päijät-Häme region is situated in Southern Finland, about $100 \mathrm{~km}$ from the capital, Helsinki. It has some 200000 inhabitants (about 4\% of the Finnish population) and consists of twelve municipalities. Its geographical and functional centre is the City of Lahti, which has about 98000 inhabitants, making it the seventh largest city in Finland. The research approach of this study is qualitative and explorative. The study includes six interviews carried out in six different university units in the Lahti University Consortium and one development meeting held with the interviewees. The study examined how to create a holistic evaluation matrix that covers all elements of the regional innovation system. The study did not take into account the activities of Lahti Science Library and the Coordination Unit of the Lahti University Consortium even if they are part of the Lahti University Consortium because the role of these units is to support the activities of the university units. 
The study began by studying existing literature in the research area. Then, based on that, the researchers created the first version of the matrix, which became a base for the development meeting and the interviews. The first version of the matrix was introduced in the development meeting, where all the interviewees commented on it together. The researchers then created a second version of the matrix and carried out individual interviews in every university unit. All of the interviewees worked at the managerial level. The interviews were theme interviews, which aimed to explore the interviewees' views on how regional effectiveness and innovative capability should be measured, how often they should be measured, and what the perspective of the measurement should be. Background information on the interviewees is presented in Tab. 1. The interviews lasted for about one and a half hours. The interviews were carried out by two researchers, who made notes and observations. The analysis of the interviews was conducted by two researchers independently, after which a common view was discussed. The interviewed participants were chosen according to the following two criteria: they should be in a leading position in the university unit, and they should have an active role in the development of the unit.

Tab. 1: Background information on the interviewees

\begin{tabular}{|c|c|c|}
\hline $\begin{array}{l}\text { Inter- } \\
\text { viewee }\end{array}$ & Organisation & $\begin{array}{c}\text { Organisational } \\
\text { position }\end{array}$ \\
\hline $\mathbf{A}$ & $\begin{array}{l}\text { University of Helsinki, Department of } \\
\text { Ecological and Environmental Sciences }\end{array}$ & Professor \\
\hline B & $\begin{array}{l}\text { University of Helsinki, Palmenia Center for } \\
\text { Research and Continuing Education }\end{array}$ & Director \\
\hline C & $\begin{array}{l}\text { University of Helsinki, Open University, } \\
\text { Lahti }\end{array}$ & $\begin{array}{l}\text { Development } \\
\text { director }\end{array}$ \\
\hline D & $\begin{array}{l}\text { Helsinki University of Technology, Lahti } \\
\text { Center }\end{array}$ & Director \\
\hline $\mathbf{E}$ & $\begin{array}{l}\text { Lappeenranta University of Technology, } \\
\text { Lahti Unit }\end{array}$ & $\begin{array}{l}\text { Head of the Unit, } \\
\text { Professor }\end{array}$ \\
\hline $\mathbf{F}$ & $\begin{array}{l}\text { Tampere University of Technology, Lahti } \\
\text { Unit }\end{array}$ & $\begin{array}{l}\text { Head of the Unit, } \\
\text { Professor }\end{array}$ \\
\hline
\end{tabular}

Because a deep understanding of the studied area was needed, the qualitative research approach was selected. In qualitative research, 
researchers typically have a relationship with every single observation. A researcher can first go back to issues that were not clear at first or in a certain context, and, second, ask the informant to focus some of his/her messages or acts on, for example, why, how and what questions, and, third, call into question some or all the actions of the informants in order to encourage them to explain and express the motives behind their activities. Identifying the nature of the informants and the motives behind their activities may be easier when the researcher has continuous or recurrent access to the context of the informant. (Miles - Huberman, 1994).

\section{Evaluation matrix of regional impacts}

The regional role of higher education institutions is becoming increasingly important. The impact of education and research on the surrounding region and society has gained increasing attention a in the university sector. The aim of this study is to present a matrix designed to function as a regional evaluation and measurement tool that can be used to identify regional problems and priorities. In addition, the evaluation matrix of regional impacts can be seen as a management tool and a tool for controlling results of organisations' actions.

\section{Challenges}

As mentioned earlier, designing and developing the evaluation matrix is a challenging task. Before starting to design and develop a measurement tool for university units, at least the following important points should be taken into account:

- impacts usually emerge after a long period of time;

- it may be difficult to show that the impacts result from the activities of the university consortiums alone;

- there are many different stakeholders, e.g. the parent university, regional decision-makers, financiers, with different needs.

Another question discussed in the interviews was how the forthcoming evaluation matrix should be implemented in practise in order for the heads of the units and decision-makers to evaluate the effectiveness and innovative capability of the university units. The interviewees were asked about what kinds of measures they would like to 
see included in the matrix and how often they think the results of the measures should be reported. As a result, the interviewees highlighted some important aspects that should be paid attention to as regards the usability and utilisation of the evaluation matrix:

- the evaluation matrix should take into account the various strategies of the Lahti region (e.g. county strategy, university strategy and Päijät-Häme regional strategy);

- the evaluate matrix should be easy to use and the results should be easy to analyse and present;

- the activities of the university units differ from each other to a large extent;

- the measures should produce both qualitative and numerical information.

Furthermore, the university units of the Lahti University Consortium are profiled very differently. The university units' operations consist of environmental, technical and economic sciences and social and pedagogical sciences. Some university units are profiled as providers of university-level education only and others in terms of research and development activities etc.

\section{Construction of evaluation matrix}

The next step of the study was to construct a matrix for evaluating the regional effectiveness and innovative capability of the Lahti University Consortium. One starting point of the study was to take into consideration challenges and strategies of the region. The different strategies of the region include similar strategy elements, such as increasing the knowhow of the region's inhabitants. Based on the literature, the evaluation matrix was designed and developed on the idea of the performance matrix. According to Riggs (1984), the matrix is especially useful for service functions and projects, in which measurements have traditionally been difficult to carry out. The evaluation matrix is presented in Table 2 . It consists of four essential sectors: (1) level of know-how, (2) development of economic life, (3) citizens' welfare and participation and promotion of sustainable development and (4) general development of the region. The selected sectors are based on the strategy of higher education and other strategies of the Lahti region. In addition, the matrix consists of five dimensions: (1) strategic comparability, (2) structures and innovative capability, (3) operations and results, (4) (direct) effectiveness and (5) 
connections inside and outside of the region. The dimensions are examined through different sectors. For example, the dimension "(direct) effectiveness" can be evaluated and analysed through the sector of "level of know-how". This reveals how the effectiveness of university unit activities has increased the know-how of the inhabitants of the Lahti region. The dimension selection was based on the literature and the results of the interviews.

The interviewees highlighted that measures should be equitable for every university unit. They also stated that the evaluation matrix should consist of two types of measures: quantitative measures of performance (e.g. how many firms or students have been assisted) and some form of qualitative assessment of practice (e.g. participation in a regional economic development partnership). There are certain characteristics that should be taken into account when selecting measures. The problems with quantitative indicators are as follows (Charles - Benneworth, 2002):

- they reflect past endowments and politics rather than current strategies;

- it is easier to measure absolute outputs than value added;

- there may be significant time-lags in reaching ultimate success.

Despite these difficulties, considerable contributions are being made to the development of performance indicators, and they are especially valuable for assessing impacts of units' activity. Qualitative assessments also have considerable shortcomings (Charles - Benneworth, 2002):

- good practices may be extremely context-dependent, and therefore the relative success of an approach may be difficult to judge;

- most qualitative evaluation consists of description, and generalisation is difficult.

The quantitative measures of the evaluation matrix have already been defined and selected. The Lahti university consortium has a measurement system that measures outputs of the university actions by quantitative measures. The interviewees stated that these measures should be taken into account when designing the evaluation matrix. As can be seen in Tab. 2 a large proportion of the measures are qualitative measures. The questions were selected based on the interviewees and the literature. 
Pekkola, S. - Ukko, J.: Measuring the effectiveness and innovative capability: Case Lahti University Consortium.

Tab. 2: Evaluation matrix of the regional impact of the Lahti University Consortium

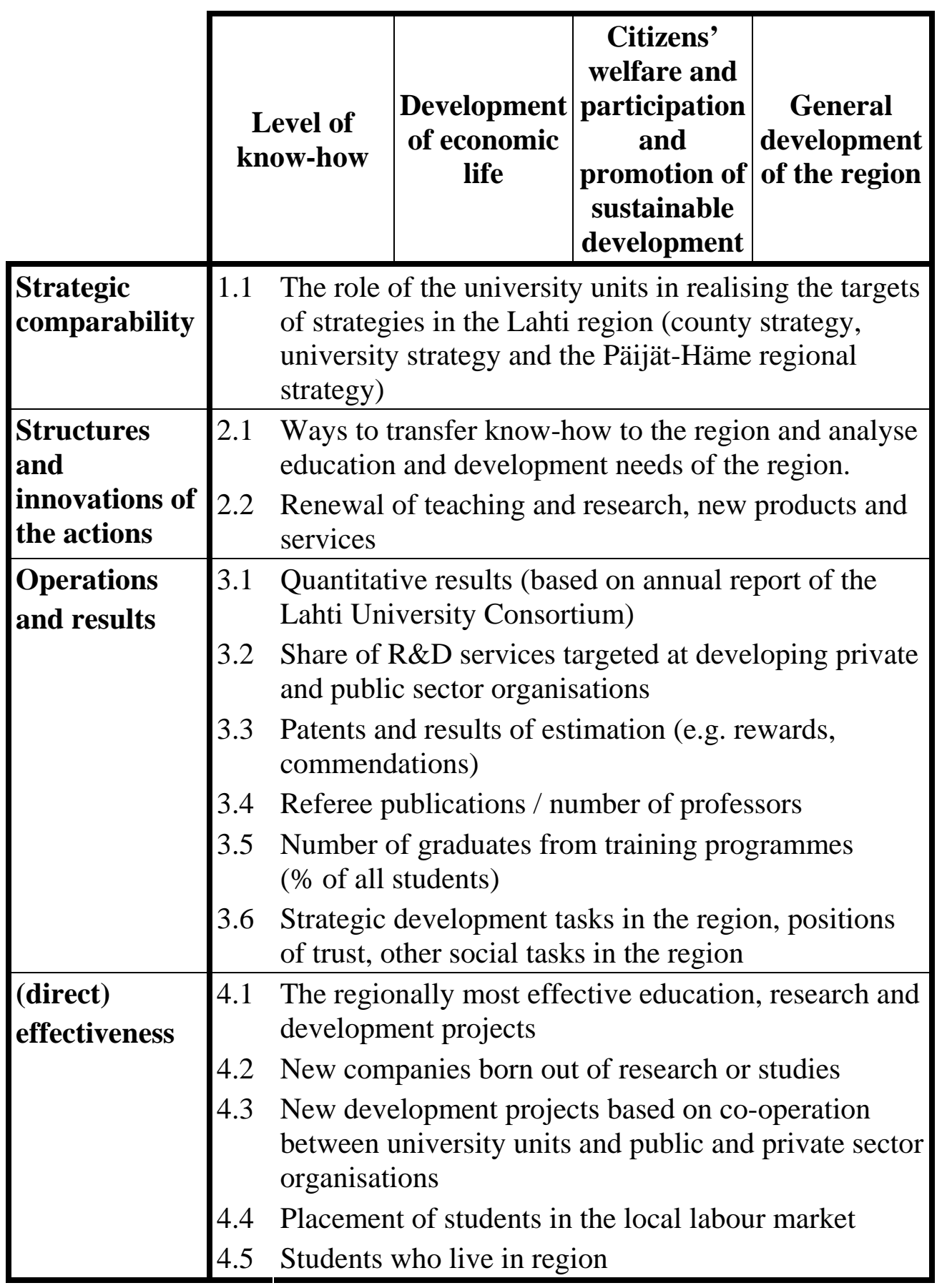




\begin{tabular}{|c|c|c|c|c|}
\hline & $\begin{array}{c}\text { Level of } \\
\text { know-how }\end{array}$ & $\begin{array}{c}\text { Development } \\
\text { of economic } \\
\text { life }\end{array}$ & $\begin{array}{c}\text { Citizens' } \\
\text { welfare and } \\
\text { participation } \\
\text { and } \\
\text { promotion of } \\
\text { sustainable } \\
\text { development }\end{array}$ & $\begin{array}{l}\text { General } \\
\text { development } \\
\text { of the region }\end{array}$ \\
\hline & \multicolumn{4}{|c|}{$\begin{array}{l}\text { 4.6 Master's thesis research and training periods carried } \\
\text { out in organisations of the region } \\
\text { 4.7 Effects of studying in the Open University (e.g. how } \\
\text { many Open University students became basic } \\
\text { students) }\end{array}$} \\
\hline $\begin{array}{l}\text { Connections } \\
\text { inside and } \\
\text { outside of the } \\
\text { region }\end{array}$ & 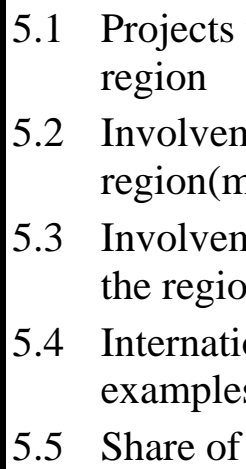 & $\begin{array}{l}\text { hent in national } \\
\text { lax. } 3 \text { examples) } \\
\text { hent in internatic } \\
\text { n (max. } 3 \text { exam } \\
\text { onal and nationa } \\
\text { ) } \\
\text { national and int }\end{array}$ & $\begin{array}{l}\text { onal co-operati } \\
\text { ples) } \\
\text { al visibility (ma }\end{array}$ & $\begin{array}{l}\text { he Lahti } \\
\text { enefiting the } \\
\text { on benefiting } \\
\text { ding } 3\end{array}$ \\
\hline
\end{tabular}

Furthermore, the university units operate very differently and in different sectors. Hence, it may even be impossible to compare different units using the same measurement system. The evaluation matrix includes 20 measures and the results of the output measures of the Lahti University Consortium. However, all measures are not meant for every university unit. Therefore, together with the other units, a university unit selects the most appropriate sector(s) and measure(s) for every dimension. This method could create the most equitable and fair matrix for all the university units.

The main idea of the evaluation matrix is to apply the matrix to all the university units of the Lahti University Consortium. Then, based on the results of the units, the evaluation group evaluates the results and forms a view on the total effectiveness of the Lahti University Consortium. The evaluation group consists of representatives from e.g. stakeholders, Local authorities and financiers. The university units carry out the measurements every year, and every third year the results are discussed 
Pekkola, S. - Ukko, J.: Measuring the effectiveness and innovative capability: Case Lahti University Consortium.

and evaluated in more detail. The university units are required to do a lot of reporting to the parent university, which is why full estimations are carried out rarely.

\section{Discussion and Conclusions}

The literature presents a number of problems and difficulties in designing and implementing a measurement system for a public sector organisation. These challenges were also perceived in this study. Two of the biggest challenges are the large group of stakeholder with different needs and the different profiles of the university units. The main result of the study is the evaluation matrix for measuring the regional effectiveness and innovative capability of the Lahti University Consortium. The Lahti University Consortium is a network university, which was established by four Finnish universities. The matrix consists of four sectors and five dimensions. The sectors are (1) level of know-how, (2) development of economic life, (3) citizens' welfare and participation and promotion of sustainable development and (4) general development of the region. The dimensions are (1) strategic comparability, (2) structures and innovations of the actions, (3) operations and results, (4) (direct) effectiveness and (5) connections inside and outside of the region. The dimension and sectors are based on strategies of the Lahti region, but the measures are also well in line with the targets set by the parent universities. The evaluation matrix includes 20 quantitative measures and the results of the earlier developed output measures. The results of the evaluation matrix were reported to the evaluation group, which then analysed the results.

As a managerial implication, the study suggests that university units can conduct the evaluation matrix in their organisation and find development issues related to regional effectiveness. In addition, for example financiers, local authorities and parent universities can gather information on the effectiveness and innovativeness of university activities. In the future, the results of the evaluation matrix could form a basis for financial support of the City of Lahti.

A limitation of the present study is that its empirical evidence is based on the views of the heads of university units. This study does not examine the relevancies of measures from the perspective of Local authorities or financiers. In the present study, we have examined measures evaluating direct impact on regional effectiveness. A number of other, indirect elements, such as impact on local tourism and the unemployment rate also 
have an effect on regional effectiveness. Despite these limitations, we believe that the matrix can be generalised to different university consortia, taking into account that strategies in different regions have different emphases.

In the future, the validity of the evaluation matrix should be tested by using it and interviewing its users. An important question in terms of validity is whether the Lahti University Consortium and the estimation group achieved the targets they were aiming for when conducting the matrix. There is also a need for instructions with regard to reporting and evaluating the results. Evaluating and updating the matrix is important because the strategies of the region will change, which means that some measures may become obsolete, while new measures need to be added.

\section{References}

[1] Adcroft, A. - Willis, R. (2005): The (un)intended outcome of public sector performance measurement. International Journal of Public Sector Management, 2005, vol. 18, no. 5, pp. 386-400.

[2] Bendheim, C. - Graves, S. (1998): Determining best practice in corporate-stakeholder relations using data envelopment: an industry level study. Business and Society, 1998, vol. 37, no. 3, pp. 306-339.

[3] Charles, D. - Benneworth, P. (2002): Regional Contribution of Higher Education a Benchmarking Approach to the Evaluation of the regional Impact of a HEI. Newcastle Upon Tyne, Centre for Urban and Regional Development Studies, University of Newcastle, 2002.

[4] Cooke, P. - Gómez Uranga, M. - Etxebarria, G. (1997): Regional Innovation Systems: Institutional and Organisational Dimensions. Research Policy, 1997, vol. 26, no. 4-5, pp. 475-491.

[5] Greiling, D. (2005): Performance measurement in the public sector: the German experience. International Journal of Productivity and Performance Management, 2005, vol. 54, no. 7, pp. 551-567.

[6] Hassan, D. (2005): Measuring performance in the healthcare field: a multiple stakeholders' perspective. Total Quality Management, 2005, vol. 16, no. 8-9, pp. 945-953.

[7] Harmaakorpi, V. (2004): Building a Competitive Regional Innovation Environment - The Regional Development Platform Method as a Tool for Regional Innovation Policy. (Doctoral 
Pekkola, S. - Ukko, J.: Measuring the effectiveness and innovative capability: Case Lahti University Consortium.

dissertation series 2004/1). Lahti, Helsinki University of Technology Lahti Center, 2004.

[8] Harmaakorpi, V. (2006): Regional Development Platform Method (RDPM) as a Tool for Regional Innovation Policy. European Planning Studies, 2006, vol. 14, no. 8, pp. 1085-1104.

[9] Harmaakorpi, V. - Tura, T. (2008): Verkostoja palveleva innovaatiopolitiikka. In: Harmaakorpi, V. - Melkas, H. (eds.): Innovaatiopolitiikkaa järjestelmien välimaastossa. Acta-sarja nro 200. Helsinki, Suomen Kuntaliitto, pp. 149-158.

[10] Kaplan, R. S. - Norton, D. P. (1992): The Balanced Scorecard Measures That Drive Performance. Harvard Business Review, 1992, vol. 70, no. 1, pp. 71-79.

[11] McAdam, R. - Hazlett, S.-A. - Casey, C. (2005): Performance management in the UK public sector: Addressing multiple stakeholder complexity. International Journal of Public Sector Management, 2005, vol. 18, no. 3, pp. 256-273.

[12] Miles, M. B. - Huberman, A. M. (1994): Qualitative Data Analysis: An Expanded Sourcebook. Thousand Oaks, Sage, 1994.

[13] Neely A. - Adams, C. - Crowe, P. (2001): The performance prism in practice. Measuring Business Exellence, 2001, vol. 5, no. 10, pp. 612.

[14] Pekkola S. - Ukko J. - Rantanen, H. (2007): Linking rewards to performance measurement: Challenges in the private and public sector. In: 4th Conference on Performance Measurement and Management Control: Measuring and Rewarding Performance in Nice. Brussels, EIASM, 2007.

[15] Pekkola, S. - Ukko, J. - Rantanen, H. (2008): Innovaatiokyvykkyyden mittaaminen Päijät-Hämeessä. Kirjassa Harmaakorpi, V. Melkas, H. (eds.) Innovaatiopolitiikkaa järjestelmien välimaastossa. Acta-sarja nro 200, Helsinki, Suomen Kuntaliitto, 2008, pp. 225-235.

[16] Poranen, A. (2006): Yliopistokeskusten rahoitusselvitys: selvitys yliopistokeskusten rahoituksesta sekä rahoituksen kehittämislinjoista. Kajaani, Oulun yliopisto, 2006.

[17] Rantanen, H. - Kulmala, H. - Lönnqvist, A. - Kujansivu, P. (2007a): Performance measurement systems in the Finnish public sector. The 
International Journal of Public Sector Management, 2007, vol. 20, no. 5, pp. 415-433.

[18] Rantanen, H. - Levä, K. - Pekkola, S. (2007b): Performance measurement implementation in a knowledge-based public organisation. International Journal Business and Systems Research, 2007, vol. 1, no. 3, pp. 343-353.

[19] Riggs, J. L. (1984): The Objective Matrix: A versatile and Proven Method to Achieve Accountability and Motivation through Productivity Measurement. In: $4^{\text {th }}$ World Productivity Congress in Oslo, Oslo, World Confederation of Productivity Science, 1984.

[20] Romijn, H. - Albaladejo, M. (2000): Determinants of Innovation Capability in Small UK Firms: An Empirical Analysis. Queen Elizabeth House Working Paper Series no. 40. Oxford, University of Oxford, 2000.

[21] Teece, D. - Pisano, G. (1998): The dynamic capabilities of firms: an introduction. In: Dosi, G. - Teece, D. - Silverberg, G. (eds): Technology, Organization, and Competitiveness: Perspectives on Industrial and Corporate Change. Oxford, Oxford University Press, 1987, pp. 17-66.

[22] Tura, T. - Harmaakorpi, V. (2005): Measuring Regional Innovative Capability. In: $45^{\text {th }}$ Congress of the European Regional Science Association. Amsterdam, ERSA, 2005.

[23] Tura, T. - Harmaakorpi, V. (2008): Lahden alueen innovaatiopolitiikka. In: Harmaakorpi, V. - Melkas, H. (Eds.): Innovaatiopolitiikkaa järjestelmien välimaastossa. Acta-sarja nro 200, Helsinki, Suomen Kuntaliitto, pp. 159-171.

[24] Ukko, J. - Tenhunen, J. - Rantanen, H. (2008): The Impacts of Performance Measurement on the Quality of Working Life. International Journal of Business Performance Management, 2008, vol. 10, no. 1, pp. 86-98. 


\title{
Measuring the Effectiveness and Innovative Capability: Case Lahti University Consortium
}

Sanna PEKKOLA - Juhani UKKO

\begin{abstract}
The aim of this study is to create a measurement system for evaluating the effectiveness and innovative capability of the Lahti University Consortium. The Lahti University Consortium is a network university, which was established by four Finnish universities and offers services provided by departments of these universities. The empirical evidence of the study is based on interviews carried out in six organisations. The result of the study represents an evaluation matrix, which measures the effectiveness and innovative capability of the Lahti University Consortium. The evaluation matrix consists of four sectors and five dimensions. The study also reveals several challenges faced in designing and implementing a performance measurement system for the Lahti University Consortium.
\end{abstract}

Key words: Effectiveness; Innovative capability; Public sector.

JEL classification: I23. 